The Legitimacy Crisis Within International Criminal Justice and the Importance of Critical, Reflexive Learning

Jeff Handmaker

\begin{abstract}
This chapter scrutinizes international criminal litigation, especially the institutions created to enforce international criminal justice: national courts and their principal jurisdictional complements; the International Criminal Court (ICC) and ad hoc tribunals. Based on Jessop's conceptualisation of crisis, the legitimacy crisis within the international criminal justice system is explained. Then, drawing on the rule of law, Mutua's critical characterisation of the human rights 'corpus' and a reflexive learning approach, it analyses different proposals to address this crisis by ending impunity through cases before the ICC and other institutions involved in prosecuting international crimes. The chapter concludes with reflections on the potential for legal learning as well as on potential future directions for international criminal litigation.
\end{abstract}

FINAL AUTHOR VERSION (Chapter 10)

Citation:

Handmaker, Jeff (2018) 'The Legitimacy Crisis Within International Criminal Justice and the Importance of Critical, Reflexive Learning' in Jessop and Knio (Eds.) (pp. 189-206) The Pedagogy of Economic, Political and Social Crises: Dynamics, Construals and Lessons London: Routledge.

ISBN: 978-1-138-06250-4 


\title{
10 The legitimacy crisis within international criminal justice and the importance of critical, reflexive learning
}

\author{
Jeff Handmaker
}

At a 2016 meeting of the American Society of International Law, Benvenisti and Nouwen (2016) explored whether the system of international criminal justice faced a 'crisis of legitimacy.' Building on an earlier debate in the European Journal of International Law in 2010, Nouwen and Werner argued that the deeply held, albeit erroneous, claim by legal advocates and academics that law is impartial renders it 'a strong tool in political struggles' (Nouwen and Werner, 2011b, p. 1164). The authors were responding to a critique of their initial contribution, which argued that, while one may seek to 'mobilise the law' in the context of a (violent) conflict, 'the structure of the law itself escapes the logic of the political' (Schotel, 2011, p. 1154).

Is the system of international criminal justice truly in crisis? Is it even possible to escape the political character of the law? In their initial contribution, Nouwen and Werner argued that '(w)hile there is nothing wrong with attempts to protect the [International Criminal] Court from political interference, portraying it as fighting the political has a disadvantage: it blinds us to the politics of the ICC itself' (Nouwen and Werner, 2011a, p. 943). More specifically, they noted, international prosecutors have claimed to stand outside the realm of politics, while at the same time taking decisions that are profoundly political (ibid., p. 962).

Concerns about the legitimacy of international criminal justice institutions have, indeed, particularly focused on the work of the International Criminal Court (ICC). The serious and entirely avoidable failure of the first ICC prosecutor to reveal exculpatory and confidential evidence to the defence counsel during its first trial against Thomas Lubanga, a former military commander in the Democratic Republic of Congo who was charged, and eventually convicted of recruiting child soldiers, nearly destroyed the prosecution's case altogether (Katzman, 2009). It has also been argued that the ICC has fallen short in investigating and prosecuting gender-based crimes, for both normative and attitudinal reasons (Mouthaan, 2011). Internal challenges have also been noted, concerning 'the scope of investigations and certain practices,' including the way in which charges are filed and confirmed, as well as more 
fundamentally - the approach of the ICC in deferring to national jurisdictions (Amnesty International, 2012, p. 4). Even the then Vice-President of the Court, acknowledged (somewhat vaguely) that there have been challenges relating to the 'internal functioning of the Court' (Kaur, 2011, p. 8). These internal weaknesses have been accompanied by a global campaign of de-legitimisation led by the former US ambassador to the United Nations, John Bolton. In essence, the US campaign threatened to withdraw military and other assistance from countries that chose to ratify the Rome Statute establishing the ICC (Bolton, 2001). The initial vehemence of the Bush-Bolton era opposition to the Court by the United States gradually gave way to a cautiously supportive position in relation to referrals by the Security Council in the cases of Sudan and Libya (although statements from the Trump administration suggest a renewed, confrontational stance). Other, more recent, external challenges to the legitimacy of the ICC have come from African countries, which have accused the ICC of being biased against leaders on the continent. Consequently, several member states parties of the Rome Statute that established the ICC have indicated their desire to withdraw (Allison, 2016).

Scholars, too, have questioned the legitimacy of the ICC, especially concerning the actions of the prosecutor, which have come under heavy fire as 'steeped in controversy' and 'selfdefeating' (Danner, 2003; Orentlicher, 2003; Goldsmith, 2003).

However, none of these critiques on the internal functioning of the ICC, or even the external legitimacy challenges, could readily be said to amount to a crisis; they can all be considered as 'accidental' in the sense that they refer to causes that are 'varied and overdetermined' and, in any event, are subject to 'well-developed routines' established for managing such crises (Jessop, 2015, p. 247). By contrast, the indeterminate character of law, which has been readily observed by critical legal scholars such as Koskenniemi (2009), elaborating on his Apology to Utopia thesis, is an objective limitation of international law generally, from which the international criminal justice system has emerged. Nouwen and Werner's argument reflects this critical reading of international law, which acknowledges the existence of deeper structural problems.

Hence, as I argue in this chapter, the real crisis of legitimacy faced by the Court and, indeed, the international criminal justice more generally, relates not so much to the existence of international legal norms and enforcement institutions as such, but to the crude and culturally essentialist way in which the ICC prosecutor, and the NGOs that support the Court, regard themselves, the perpetrators, and the victims/survivors of international crimes. The crisis, in other words, stems from how the Court itself, particularly in the discourse of the prosecutorial office, which is represented as a non-political administrator of justice in response to allegations of international crimes, is taking decisions that fail to consider the complex social, cultural and political contexts in which these crimes took place.

The system of international criminal justice, including law and legal institutions, is profoundly political. Legal scholars frequently 
under-estimate the extent to which legal practice involves - indeed demands - systematic, strategic reflection. By the same token, then, the crisis of legitimacy facing international criminal justice is a 'moment for reflection' (Jessop, 2015, p. 255). Like Nouwen and Werner, Harmen van der Wilt (2011) has acknowledged that, in responding to the many criticisms of universal jurisdiction for international crimes, and to the work of the International Criminal Court, it is helpful to analyse the work of international criminal justice in an inter-disciplinary way.

Having set out the issues, the second part of this chapter presents a framework for analysing the liberal underpinnings of the international criminal justice system. Part three, drawing on Mutua's (2001) critical assessment of the human rights corpus, focuses on how efforts to invoke the international legal system in order to manage international criminal prosecutions have proved problematic. Part four explores the implications of a strategic approach to legal advocacy for reflexive (legal) learning and the management of crises through international criminal justice mechanisms, focusing on the dimensions of the legitimacy crisis that are generated by the international legal system itself, which Koskenniemi $(2009$, p. 12) defines as 'managerialism'.

The concluding part comments on the extent to which strategic legal advocacy, a critical approach to legal interpretation and an approach of critical, reflexive learning present opportunities for lawyers to engage explicitly with the politics of international law in a way that creates opportunities for 'learning from' the legitimacy crisis (Jessop, 2015, p. 257) and thereby enhances, rather than undermines the role of law as a mediator of crisis.

My analysis relies on various sources of data. They include the comprehensive portrayal of the international criminal justice system and, especially numerous statements made by the ICC prosecutor in the acclaimed documentary film The Reckoning (2003). I also rely on my extensive interactions with ICC staff members, scholars, journalists and other followers of the ICC's work over more than a decade since the Court's establishment in 2002. This material is complemented by on-the-record statements made by the initial prosecutor of the Special Court of Sierra Leone, David Crane, and other representations of international criminal justice issues, in academic commentary and in the media.

\section{A Framework for Analysing Legal Mobilisation in International Criminal Justice}

This part provides a framework for analysing the pursuit of international criminal justice through international and national courts. This framework has three features. It first introduces the liberal rule of law concepts that have underpinned a civic protection charter, which has, in turn, become the legal basis upon which the international criminal justice system emerged. Second, it deploys Mutua's Savages, Victims and Saviours (or SVS) metaphor to critique liberal assumptions underpinning human rights and to evaluate the efforts of lawyers working within the international criminal justice system who struggle to come to grips with the complex social and cultural contexts in which law functions. Third, it adopts a reflexive learning approach, which I will argue below provides a more grounded basis for approaching international crises through legal approaches. 
From the 1940s until the 1960s, a then-small community of nation-states oversaw the creation of what I have described as a 'civic protection charter' that significantly altered the relationship between civic actors and the state (Handmaker, 2009, pp. 26-29). This emerged in three phases. The first phase of the charter featured four key normative developments in international law and the development of a system of global governance, from the creation of the UN by way of the Charter of the United Nations (1945), to the establishment of human rights protection standards by the Universal Declaration of Human Rights (United Nations, 1948). Consolidation of the Charter followed, building on earlier treaties governing the conduct of war and humanitarian protection standards through the Fourth Geneva Convention of the International Committee of the Red Cross (1949). This included an obligation on states to prosecute combatants whose actions resulted in a 'grave breach' of the Conventions. The second phase began in the $1960 \mathrm{~s}$ and continued until the mid-1990s, primarily under the auspices of the United Nations, but also in different regions of the world. Covenants on civil and political rights, as well as on economic, social and cultural rights that both came into force through the United Nations (1966a and b) helped to develop and establish the principles of the Universal Declaration of Human Rights, and created institutions to oversee state compliance with these treaties. Other international treaties came into being, accompanied by administrative structures that aimed to ban racial discrimination, prohibit torture (United Nations, 1984) and promote and protect the rights of women, children, migrant workers and persons with disabilities, as well as the problem of enforced disappearances. Finally, a third phase of civic protection began in the mid-1990s and continues to the present day, featuring the establishment of specific, though mostly ad hoc efforts to prosecute international crimes through UN-created institutions and national court systems, as well as agreement in the late 1990s on the Statute of Rome, the liberal legal basis for a permanent international criminal law system.

Civic actors, both individuals and collectives, have mobilised this charter to advocate for state accountability and to promote normative entrenchment at the domestic level to protect fundamental human rights, to make claims against states and ultimately agents of a state, based on liberal-internationalist conceptualisations of the rule of law (Ignatieff, 1999; Ignatieff and Gutmann, 2001). The domestication of human rights norms has not always led to greater respect for human rights (Arts and Handmaker, 2010). Indeed, uneven implementation 
and sometimes reluctance by states or their institutional organs to respect, protect and fulfil human rights has triggered a growing consciousness among civic actors, and especially lawyers, that international human rights can, and should, be mobilised in various ways, whether in domestic legal argumentation, as the basis of other forms of social justice struggle (Klaaren, Handmaker and Dugard, 2011) or through naming and shaming (Donnelly, 1989; Korey, 2003; Risse, Ropp and Sikkink, 1999). As explained in the next section, one of the explanations for the uneven treatment of international human rights norms relates to their liberal character.

\section{A plea for self-criticism through the SVS metaphor}

In a seminal article that addressed the failings of international human rights law and the movement that accompanies it, Makau Mutua (2001) produced a stirring critique of its liberal underpinnings, concluding with a plea for self-criticism by those involved in the collective 'corpus' of human rights. Departing from a classic, liberal depiction of human rights, Mutua saw the human rights movement as being characterised by a three-sided 'prism' of savages, victims and saviours, which he referred to as the 'SVS metaphor'. He explained this prism as having pre-determined characteristics, notably barbarism (of the state), victimhood (of those subject to human rights violations), and a saviour mentality of mainly Western organisations intervening to prevent or respond to human rights abuses.

As I have argued elsewhere and develop in this chapter, Mutua's critical interpretation of the human rights corpus through the SVS metaphor also reflects problems concerning popular representations of international criminal justice and explains its crisis of legitimacy (Arnoldussen, 2011; Handmaker, 2011). Mutua's critique of the international human rights regime forms part of a radical critique of international law, which applies to a wide range of international legal vocabularies, from international human rights law, to international economic law. Known as Third World Approaches to International Law or 'TWAIL,' these approaches regard the regime of international law, particularly in relation to developing countries, as largely 'illegitimate' in that it 'legitimizes, reproduces and sustains the plunder and subordination of the Third World by the West' (Mutua, 2000, p. 31). Reynolds has argued that TWAIL continues to be relevant in critiquing the function of international law, which is increasingly invoked to address what he regards as a state-imposed mantra of a 'permanent state of emergency' (2017, p. 7). For example, drawing on this approach, Reynolds analyses Israel as a 'settler colonial state,' which permits the treatment of the occupied territory of Palestine as a 'space for exception' in which international law is readily set aside (ibid., pp. 195-243). Reynolds also applies this approach to analyse Australia's treatment of aboriginal people in imposing a state of emergency in the Northern Territory, which has had profound consequences for sovereignty and land ownership (ibid., pp. 244265).

These critical approaches to international law reinforce Koskenniemi's (2009) argument that one must look beyond the normative liberal tendency 
that underpins the world view of many lawyers, that is, look beyond simply the content of law and the largely techno-managerial way in which it is enforced. As discussed in the next section, this has profound implications for legal education.

\section{Reflexive legal learning}

Originally derived from Pierre Bourdieu's scholarly work in the 1980s and later incorporated into his Reflexive Sociology (Bourdieu and Wacquant, 1992), a substantial body of scholarly writing has emerged on the importance of 'reflexive learning' in education, including legal education. Within this complex body of scholarly work, Anthony Amsterdam (1984) argued for the importance of clinic-based education as a core component of law school education. This plea related to Teubner's (1983) argument in favour of 'reflexive law,' which engaged with broader social considerations aimed at addressing fundamental inequalities. Thus, Teubner argued that "unlike formal law, (reflexive law) does not accept "natural" subjective rights. Rather, it attempts to guide human action' (1983, p. 255). Rather than teaching merely the content of law, there was a compelling argument, he claimed, that law schools should also be involved in teaching the practice of law. Hence, legal practice involves much more than regurgitating legal norms: it also requires an understanding of how law structures society and economic relations.

The scholarly arguments in favour of clinic-based legal education continued to take hold in the 1990s, where the work of Shalleck (1995) and Quigley (1996), engaged with, among other factors, the social justice dimensions of doing clinical work. Scholarly work of the early 2000s, such as Neumann (2000), noted the largely unchanged approach to legal education in the US, which under-valued the crucial clinical dimension (and still does). Countering the unjustified resistance towards this pedagogic strategy, Voyvodic and Medcalf (2004) went a step further and emphasized the value of an interdisciplinary approach to clinical legal education. Such a socio-legal approach to law had earlier been endorsed by Friedman (1986) in relation to law school education and by Nelken (2004), more specifically in relation to legal culture, as well as by Scheppele (2004) in relation to social rights. In other words, the economics, sociology and politics (including gender-relations) played as much, if not a greater role in the outcome of legal disputes than the content of law itself. Finally, Ashar (2016) argued that clinic education was crucial to democratic lawyering and emphasized the importance of developing knowledge bases, while Babacan and Babacan (2017) highlighted the role of accessible clinical education as enhancing civic consciousness.

The possibility of reflexive legal learning from the management of crises is directly related to the way in which legal education is organised. As Jessop has observed, a 'crisis does not automatically lead to learning: cognitive capacities may be lacking ... It can also involve different degrees of reflexivity, i.e., learning about learning.' (2013, p. 242). Elaine Mak confirms this 
dilemma in her critique of legal education, observing that the so-called 'T-shaped lawyer' should be a legal professional that 'is able to cope with these challenges based on deep legal knowledge and skills... with broad knowledge of other disciplines and academic skills' (2017, p. 7). Mak goes on to observe that 'legal education does not sufficiently prepare law school graduates to master the competences' required of other disciplines (ibid., p. 8). In other words, most law graduates lack the cognitive capacities for reflexive learning, rarely possessing the knowledge to effectively manage complex economic and other crises, or even to relate to colleagues with non-legal backgrounds.

In short, appreciating the challenges, as well as the social, economic and political significance of reflexive learning in legal education are indispensable components of understanding about the potential of law to manage complex disputes. This resonates with the position that 'learning from crisis' allows for opportunities to reflect on that crisis, and the implications this has for future crisis management (Jessop, 2015, p. 257).

\section{Analysing the Pursuit of International Criminal Justice}

Drawing on the framework of analysis from the previous section, the emergence of an international criminal justice system as part of the global civic protection charter is assessed. This section then critiques efforts by various civic, state and intergovernmental actors forming part of the international criminal justice movement to end impunity for international crimes through international criminal law and justice institutions.

\section{The emergence of an international criminal justice system}

The development of international criminal justice as a system is a relatively new development, comprising the most recent component of the civic protection charter, and it is still based on liberal understandings of the rule of law. The Tokyo and Nuremburg Tribunals were established to prosecute alleged perpetrators of war crimes in Asia and Europe following the Second World War, while the International Criminal Tribunal for the former Yugoslavia and the International Criminal Tribunal for Rwanda were created half a century later to address widespread violations following civil wars in these two countries in the 1990s (Klip and Sluiter, 1999). Special and hybrid courts have also been established, including the Special Court for Sierra Leone, the Extraordinary Chambers in the Courts of Cambodia and the Special Tribunal for Lebanon. All these courts and tribunals have gradually developed their own jurisprudence. The jurisdictions of these courts, both at national and international levels, are a product of state-driven processes. It is therefore doubtful whether civil society organisations can be said to have formed the ICC, although the substantial contribution by NGOs has led to such claims being made (Glasius, 2006).

Following the establishment of the ICC, the exercise of national jurisdiction for international crimes received additional, normative impetus. Many countries 
that ratified the Rome Statute have passed implementing legislation to prosecute alleged perpetrators, regardless of the nationality of the alleged perpetrator or victims, or where the crimes took place. Because of these normative and institutional developments, individuals and corporations can be held directly accountable for international crimes in a variety of jurisdictions. Van den Herik acknowledges the value of having universal jurisdiction over international crimes. She writes that 'one of the dark side effects of the phenomenon of globalisation is that also criminals and crime are increasingly moving beyond borders. It is thus by necessity that extraterritorial criminal jurisdiction is and should be exercised' (Van den Herik, 2009, p. 225).

By insisting on the necessity that states exercise extraterritorial jurisdiction, Van den Herik implied that criminal prosecution is the most desirable direction for international criminal justice to take. Indeed, national prosecuting authorities in certain influential states that have established complementary systems for prosecuting international crimes at the domestic level, and notably: Spain, the United Kingdom, Switzerland, Belgium, South Africa and the Netherlands. In the enforcement of international criminal justice, States routinely interact with NGOs, which monitor the ICC regarding its implementation, and lobby in relation to specific complaints aimed at alleged perpetrators, and urging state prosecuting authorities to take action (Glasius, 2006, p. 23). Accordingly, the perceived 'necessity' of prosecuting international crimes at the ICC, and the interweaving relations between civic actors and states involved in enforcing international criminal justice make it very difficult to recognize the crisis of legitimacy surrounding the international criminal justice system, let alone evaluate that crisis.

\section{Critiquing the international criminal justice system through the SVS metaphor}

The pursuit of international criminal justice can be usefully critiqued using Mutua's SVS metaphor. Surprisingly, critics of the ICC remain very rare, and have mostly confined their objections to the legal basis and external pressures facing the Court. It is therefore productive to explore the social and cultural underpinnings of the international criminal justice system, and particularly the role of international prosecutors. For this, Mutua's SVS metaphor is a useful analytical basis for critiquing the international criminal justice system, or at least the popular representation of this system.

The documentary film The Reckoning (2003) accurately portrays the international criminal justice system and, in particular, the functioning of the ICC prosecutor, Luis Moreno Ocampo, as engaged in legal-institutional mobilisation against the alleged perpetrators of international crimes. However, in focusing on the legal functioning of the Court, the film fails to address what really underpins the conflicts addressed by the international criminal justice system, the violence that emerges from these conflicts, and the realistic prospects of fostering international criminal justice solely through institutions such as the ICC. In other words, the film successfully conveys the perspective of the ICC prosecutor, while leaving many crucial questions unanswered. 
While the failure to address these questions and to take a more critical line is hardly surprising, for reasons mentioned earlier in this section, the representation of the international criminal justice system and the legal advocates who are engaged in a form of politics - from the ICC prosecutor to the NGOs who support him/her - deserve a deeper, critical analysis.

The organisation that produced the film, the International Centre for Transitional Justice, is part of a global network of NGOs. While the film is a mostly uncritical representation of the ICC and, especially, its first prosecutor, Luis Moreno Ocampo, the film vividly reveals how the SVS metaphor is deployed.

In its depiction of barbarism, the film shows scenes of marauding rebels, allegedly led by Thomas Lubanga (later brought to trial at the ICC), yelling and waving crude weapons as they appear engaged in the pillaging of communities. Another notable scene in the film depicts members of the government-led Sudanese militia group Janjaweed, galloping on horseback and brandishing what appear to be crude swords and other weapons. Numerous simplistic representations in the film of the Lord's Resistance Army (LRA) rebel group in Northern Uganda complete this picture of a 'savage' African culture, and confirm my own personal impressions of attitudes held by staff members of the ICC, and especially those working in the Office of the Prosecutor.

Crane conveyed similar images of savagery in his opening statement during the trial of alleged leaders of the Revolutionary United Front (RUF) at the Special Court of Sierra Leone:

This is a tale of horror, beyond the gothic into the realm of Dante's inferno...Their alleged crimes against humanity cannot justly or practically be ignored, as they were the handmaidens to the beast - the beast of impunity that walked this burnt and pillaged land - its bloody claw marks in evidence on the backs of the hundreds of thousands of victims in this tragic conflict (Special Court of Sierra Leone, 2004, pp. 2-5).

The Reckoning further depicts stereotypical victims alongside the representations of the savage culture ostensibly behind their persecution. Images in the film include those of helpless women who have been viciously raped and beaten after a brutal raid by the LRA on one of their euphemistically named 'protected villages,' a displaced persons' camp in Northern Uganda. Images are also shown of burning corpses after an attack on a village by militias in the Congo, and there are stomach-churning scenes of a young boy whose leg is torn to shreds after the LRA forcibly tethered him to prevent him escaping. No effort is made to ask why people had been (forcibly) transferred to these villages in the first place (Dolan, 2009).

Child soldiers, both in terms of their rights and in terms of international criminal accountability, have been extensively written about (Arts and Popovski, 2006; Honwana, 2006; Wessels, 2006; Drumbl, 2012). Global campaigns, including A World Fit for Children, have been launched to end the recruitment of child soldiers and to prosecute individuals who have been involved in forced recruitment. However, the preoccupation of scholars, NGOs and agencies with this important topic has led to a 

Crises: Dynamics, Construals and Lessons (2018, London: Routledge).

'distorted understanding' of the conflicts in which child soldiers have been embedded (Dolan, 2002, p. 145). In addition, the understandably strong emotions generated by the recruitment of children in armed conflicts, and other violations associated with their recruitment, have been exploited by prosecutors. Crane, referring to a 'lost generation' of children who had been forcibly recruited into the army of the RUF rebels, noted that:

There is in Sierra Leone an entire lost generation of children, lost souls wallowing in a cesspool of physical and psychological torment. ...This lost generation, victim or perpetrator, are overall victims of this joint criminal enterprise that was led by Sesay, Kallon, and Gbao among others. Children will come before you and testify in effect, 'I killed people! I am sorry, I didn't mean it' (Special Court of Sierra Leone, 2004, p. $11)$.

It is impossible not to experience emotions when confronted by such hideous examples of human rights violations, particularly when they involve children. But how do these ghastly images help us to understand the reasons why such crimes were committed, or the immense challenges faced by the governments and societies of Uganda and Sierra Leone to compensate the victims, and provide their citizens with a stable and secure future? Should the mere existence of 'protected villages' not generate questions about Uganda's forced resettlement of people to these compounds - which were then targeted by LRA rebels, helping to create a humanitarian crisis? Is it helpful to refer to former child soldiers as a 'lost generation,' suggesting they are beyond hope or redemption?

But perhaps the most notable aspect of the Reckoning is its depiction of the saviours. Referring to his role as a prosecutor in 1985 against Argentinian generals accused of grave crimes, Ocampo comments: 'All my life I had the idea that this was the most important work of my life... and now I feel it was just my training...to do this job'. These and other statements by Ocampo, Chung and others working in the Office of the Prosecutor of the International Criminal Court reproduced in this section come from the documentary film by Yates (The Reckoning, 2003).

As a self-appointed 'saviour,' Ocampo has no qualms about insisting that he take action, brushing aside concerns raised by his colleagues that he was moving too fast in investigating the LRA in Uganda and thereby risking further destabilising the situation there. Ocampo responded: 'I knew I had to run. I had to show very quickly some outcome, some results.'

The notion of helpless victims faced with a 'savage' culture, awaiting the intervention of a (Western-based) saviour is reinforced by Christine Chung, an ICC principal investigator interviewed in the film, who makes it clear that her presence in the field is necessary: 'In the course of the investigation it's critical to go there. You have to understand the culture, the environment and you want to meet the people that are going to be your potential witnesses.'

Is it helpful to depict barbaric and savage cultures pitted against helpless victims, themselves dependent on (largely Western) intervention? Does 
prosecutor Crane's depiction of 'gothic' horror help us to understand what led to the war in Sierra Leone, and what is needed to reconstruct the country and its society? Should a durable peace be part of the Court's calculation in any way, and is the 'quest for international justice' enough? Should we not be encouraged to ask critical questions in order to strengthen the international criminal justice system? Apart from an emphatic 'yes' to the last question, I do not pretend to provide satisfactory answers to these political questions. But, the debate must continue.

\section{Legal Advocacy and the Potential for Reflexive Legal Learning}

In this section I will elaborate on how legal learning can take place through a strategic encounter with legal advocacy, by reflecting on reflexive learning as an analytical lens. More specifically, I will explore the extent to which strategic legal advocacy presents opportunities for lawyers to engage with the politics of international law, by connecting to the broader social considerations of law (Teubner, 1983), as it relates to the global system of international criminal justice and, in particular, to prosecutorial discretion as well as institutional inquiries' (Jessop, 2015, p. 257) into the failings of the ICC in particular. Furthermore, I will explain how strategic legal advocacy, and an approach of reflexive legal learning, depend on a close-knit coalition of not just lawyers, but various stakeholders with multi-varied, but ultimately compatible interests and expectations that engage with the social justice dimension of legal practice (Shalleck, 1995; Quigley, 1996).

\section{Learning how to adopt a contextualised approach to prosecutorial discretion}

The highly selective application of the law that gives prosecutors wide discretion is woven into the text of the Rome Statute of the ICC (United Nations, 1998); it is also entrenched in national legislation (Zegveld and Handmaker, 2010). These international and national legal norms, together with procedural and evidentiary rules, closely circumscribe the criteria for prosecuting international crimes, but still allow for a wide margin of interpretation. Such rules may be triggered by necessity, in particular the existence of limited resources. But, there is another crucial reason as well that leads to a clear structural bias and is crucial from a legal learning standpoint, namely the absence of a contextual understanding on the part of those pursuing international criminal justice.

The mission of the law and legal institutions engaged in international criminal justice is essentially twofold. First, the mission is to frame rules to ensure that consequences attach to gross violations of human rights and International Humanitarian Law (IHL). Second, it is to ensure that these rules are applied in a consistent and even-handed manner. However, politics always play a role, both in framing the rules and in implementing them. Justice is never blind, and is nearly always available only to the perceived 'victors' of a specific conflict. 
Legal advocates, from the prosecutors who bring such cases before the courts, to the defence counsel who represent the alleged perpetrators, and even the non-governmental organisations (NGOs) who advocate for attention to specific issues, all bring their own, particular appreciation or consciousness of the law to their tasks. Many legal advocates, often without much critical reflection, seek to mobilise the law without necessarily addressing the social and political context in which such crimes have taken place. International prosecutors in particular rarely acknowledge openly the politics of what they do, with some notable exceptions, such as the former chief prosecutor of the International Criminal Tribunal for the former Yugoslavia, Louise Arbour (2008). By purporting to be neutral and impartial, these legal advocates mask the ideological basis upon which strategic decisions are taken to investigate, prosecute and punish international crimes.

The liberal ideological basis upon which decisions are taken to investigate and prosecute can be revealed through a careful examination of what cases eventually find their way to the courts and are prosecuted, accompanied by a contextual assessment of why some cases are chosen over others.

Part of the complexity in explaining the dynamics of international criminal justice through prosecution for international crimes, is that international law is not the homogenous system it once was. It has evolved into what Koskenniemi has described as 'a wide variety of specialist vocabularies and institutions' $(2009$, p. 12). The international criminal justice system, which was established to hold perpetrators accountable, is one of the most recent products of this evolution, and is no less contested than any other specialist area of international law. As discussed by Drumbl (2005, p. 1295), there is some dispute as to whether a system of international criminal justice really exists, from an institutional and/or doctrinal standpoint. I tend to agree with Sands (2003), who indicates that there is such a system of international criminal justice, particularly following the creation of the International Criminal Court in 2002. Indeed, the international criminal justice system is riddled with practical and legal obstacles, and, as I have already suggested, operates on a highly selective basis. The system also lacks a coherent policy framework. As Sieff and Vinjamuri have observed: 'Despite the plethora of motivations that have inspired war-crime trials historically, an international strategy for indicting war criminals cannot be justified in the absence of clear policy goals' (2002, p. 103).

\section{Learning how to build national capacities to prosecute}

In an article published nearly a decade after he presented his critique of the international human rights system through the 'SVS metaphor,' Mutua reflected on how the international criminal justice system, and the ICC in particular, could be improved (Mutua, 2010). He called on the ICC, and others within the system, including NGOs, to appreciate the need to build civil society in countries being investigated by the ICC. More fundamentally, Mutua demanded a more 'holistic understanding of the root causes of 
the culture of impunity and the seemingly intractable ethnic, social, and political problems' (ibid., p. 2). Rather than take legal action against the perpetrators of grave crimes itself, Mutua has insisted that the ICC take seriously its clearly prescribed role in supporting domestic legal procedures (ibid., p. 3). This is affirmed by Nouwen (2013) in her comprehensive study of the failings of the international criminal justice system, and especially the ICC, to realise its core function of promoting complementary systems to prosecute international crimes in the national court systems of Uganda and Sudan.

Beyond building national capacities to prosecute, the international criminal justice system must dispense justice in a much more even-handed (i.e. socially just) manner, not least in light of growing concerns that international criminal justice fails to take seriously basic principles of due process, including rights of the accused through what Munyard has regarded as a 'blind paper shuffle' (Munyard, 2010).

\section{Acknowledging the dangers of managerialism}

Perhaps the most perplexing dimension of legal learning for both civic and state advocates who support the ICC and the complementary role of national jurisdictions is the persistent danger, frequently noted by Koskenniemi (2009), that engagement in the international criminal justice system might lead to simplistic 'managerialism' solutions. More specifically, Koskenniemi warned of the common assumption that international problems...should be resolved by developing increasingly complicated technical vocabularies for institutional policy-making' (2009, pp. 13-18). In other words, it would be a mistake to compensate for the failures of rules in the international criminal justice system simply by creating new rules. It is crucial to engage with the politics of the crisis of legitimacy facing the system.

Contrary to the perception of former ICC prosecutor Ocampo, who claimed to be 'putting a legal limit to the politicians' and 'policing the borderline' by drawing a distinction between what is political and what is criminal, Nouwen and Werner observe that 'determining who is "on the political side" or not is inherently political, especially when it involves the labelling of groups and individuals as international criminals' (Nouwen and Werner, 2011a, p. 962). Furthermore, in determining whether a 'crisis' of legitimacy in criminal justice exists, one must critique the nature of the crisis itself; otherwise, the term 'loses credibility' and 'business seems to go on as usual, until the next "crisis" comes around' (Benvenisti and Nouwen, 2016, p. 206).

As in any political process, legitimacy concerns will continue to be raised. The system for prosecuting persons suspected of international crimes, whether through international tribunals such as the ICC or via a national court, are far from ideal. Addressing these concerns requires a more conscious and deliberate engagement with the broader political questions 
surrounding international criminal justice - from the decision to investigate and eventually prosecute, to the determination of guilt or innocence - rather than merely following the bland legal content or procedures through which the law is implemented.

Managerialism concerns aside, acknowledging the politics behind international criminal justice opens the possibility that learning from the international criminal justice system is administered by legal-technocrats and ideologues only. By opening a more critical debate, advocates within the international criminal justice system may ensure that not only lessons are learned from the crisis of legitimacy faced by the system, but that new policies may be shaped. This could take the form of a 'call for quick action' that is directed against 'those directly affected' by the crisis - namely the closely-watching constituency of world leaders, NGOs and the victims of individual and mass atrocities - in a highly productive way (Jessop, 2015, p. 258).

\section{Conclusion}

This chapter has demonstrated that, contrary to the largely legal-doctrinal thinking of most lawyers engaged in international criminal justice, efforts by legal advocates to end impunity for international crimes are obviously a form of politics. By adopting an approach of critical, reflexive learning, lawyers are better positioned to explicitly engage with the politics of international law in a way that enhances, rather than undermines the role of law as a mediator of crisis.

Unlike the multiple external challenges posed by the USA and the Africa block of member states that have withdrawn from the system, or threatened to do so, the real crisis of legitimacy faced by institutions such as the ICC will deepen if the structural bias towards under-developed countries that is framed by an essentialised understanding of states, the victims of human rights violations and the role of international institutions and advocates as saviours are not addressed. In other words, the current crisis is largely of the system's own making. This perception stems from a combination of the bombastic attitude of international prosecutors such as Ocampo and Crane, the self-serving interests of states, and the uncritical stance of a large body of NGOs that have played an important role in the establishment and functioning of the international criminal justice system and to some extent reinforce its crisis of legitimacy. Consistent with Ignatieff's assessment of the human rights movement in general, the international criminal justice movement 'is facing of a crisis of self-doubt, not because it is failing, but because it has not dealt honestly with the implications of its success' (Ignatieff, 1999, p. 12).

By contrast, considering the 'structural bias' of institutions (Koskenniemi, 2009, p. 9), including courts and tribunals established to administer international criminal justice, strategic legal advocacy can strengthen the legal mechanisms to investigate, prosecute and adjudicate international crimes in a consistent and even-handed manner. Accordingly, it may be possible to move 
away from a mentality of Savages, Victims and Saviours, and engage in a more honest and transparent politics as part of collective global efforts to end impunity and address the legitimacy crisis facing the international criminal justice system.

\section{References}

Allison, S. (2016) 'African revolt threatens international criminal court's legitimacy', The Guardian, 27 October.

Amnesty International (2012) 'The International Criminal Court: coming challenges, issues and conclusions', Statement presented at the Justice for All Conference, 15 February. Sydney, Australia: University of New South Wales.

Amsterdam, A. (1984) 'Clinical legal education: a 21st Century Perspective', Journal of Legal Education, 34(4), pp. 612-618.

Arbour, L. (2008) 'The responsibility to protect as a duty of care in international law and practice', Review of International Studies, 34, pp. 445-458.

Arnoldussen, T. (2011) 'The Reckoning: a different perspective?' Recht der Werkelijkheid, 32(3), pp. 107-111.

Arts, K. \& Popovski, V. (eds.). (2006) International criminal accountability and the rights of children. The Hague: Hague Academic Press.

Arts, K. \& Handmaker, J. (eds.) (2010) 'Cultures of constitutionalism' subsection in Frischman, M. \& Muller, S. (eds.), The dynamics of constitutionalism in the age of globalisation. The Hague: Hague Academic Press, pp. 57-109.

Ashar, S. (2016) 'Deep critique and democratic lawyering in clinical practice', California Law Review, 104, pp. 201-232.

Babacan, A. \& Babacan, H. (2017) 'Enhancing civic consciousness through student pro bono in legal education', Teaching in Higher Education, 22(6), pp. 672-679.

Benvenisti, E. \& Nouwen, S. (2016) 'Leaving legacies open-ended: an invitation for an inclusive debate on international criminal justice', AJIL Unbound, 110(3), pp. 205-208.

Bolton, J. (2001) 'The risks and weaknesses of the International Criminal Court from America's perspective', Law and Contemporary Problems, 64, pp. 167-180.

Bourdieu, P. \& Wacquant, L. (1992) An invitation to reflexive sociology. Chicago: University of Chicago Press.

Danner, A. (2003) 'Enhancing the legitimacy and accountability of prosecutorial discretion at the International Criminal Court', American Journal of International Law, 97, pp. 510552.

Dolan, C. (2002) 'The optional protocol: in the best interest of whom?', Journal of Conflict, Security and Development, 2, pp. 141-148.

Dolan, C. (2009) Social torture: the case of northern Uganda, 1986-2006. Oxford: Berghahn.

Donnelly, J. (1989) Universal human rights in theory and practice. Ithaca: Cornell University Press.

Drumbl, M. (2005) 'Pluralizing international criminal justice', Michigan Law Review, 103, pp. 1295-1328.

Drumbl, M. (2012) Reimagining child soldiers in International law and policy. Oxford: Oxford University Press.

Friedman, L. (1986) 'The law and society movement', Stanford Law Review, 38(3), pp. 763780 . 
Glasius, M. (2006) The International Criminal Court: a global civil society achievement. New York: Routledge.

Goldsmith, J. (2003) 'The self-defeating International Criminal Court', University of Chicago Law Review, 70, pp. 89-104.

Handmaker, J. (2009). Advocating for accountability: civic-state interactions to protect refugees in South Africa. Antwerp: Intersentia.

Handmaker, J. (2011) 'Facing up to the ICC's crisis of legitimacy: A critique of the reckoning and its representation of international criminal justice', Recht der Werkelijkheid 32(3), pp. 100-106.

Herik, L. van den (2009) 'The difficulties of exercising extraterritorial criminal jurisdiction: The acquittal of a Dutch businessman for crimes committed in Liberia', International Criminal Law Review 9, pp. 211-226.

Honwana, A. (2006) Child soldiers in Africa. Philadelphia: University of Pennsylvania Press.

Ignatieff, M. (1999) Whose universal values? The crisis in human rights. Amsterdam: Stichting Praemium Erasmianum.

Ignatieff, M. \& Gutmann, A. (eds.) (2001) Human rights as politics and idolatry. Princeton: Princeton University Press.

International Committee of the Red Cross (ICRC) (1949) Convention relative to the protection of civilian persons in time of war. United Nations Treaty Series, v. 75. Geneva: ICRC.

Jessop, B. (2013) 'Recovered imaginaries, imagined recoveries: a cultural political economy of crisis construals and crisis-management in the North Atlantic Financial Crisis', in Benner, M. (ed.) Beyond the global economic crisis: economics and politics for a postcrisis settlement. Cheltenham: Edward Elgar, pp. 234-254.

Jessop, B. (2015) The symptomatology of crises, reading crises and learning from them: Some critical realist reflections, Journal of Critical Realism 14(3), pp. 238-271.

Katzman, R. (2009) 'The non-disclosure of confidential exculpatory evidence and the Lubanga proceedings: how the ICC defense system affects the accused's right to a fair trial', Northwestern University Journal of International Human Rights 8, pp. 77-101.

Kaur, H. (2011) 'The International Criminal Court: current challenges and perspectives', Keynote address at the Salzburg Law School on International Criminal Law. Salzburg, Austria: Salzburg Law School.

Klaaren, J., Handmaker, J. \& Dugard, J. (eds.) (2011) 'Public interest litigation in South Africa: special issue introduction', South African Journal on Human Rights, 27(1), pp. 17.

Klip, A. \& Sluiter, G. (1999) Annotated leading cases of International Criminal Tribunals. Antwerp: Intersentia.

Korey, W. (2003) NGOs and the Universal Declaration of Human Rights: a curious grapevine'. New York: St. Martin's Press.

Koskenniemi, M. (2009) 'The politics of international law - 20 years later', 20 European Journal of International Law, 20(1), pp. 7-19.

Mak, E. (2017) The T-shaped lawyer and beyond: rethinking legal professionalism and legal education. The Hague: Eleven International Publishing.

Mouthaan, S. (2011) 'The prosecution of gender-based crimes at the ICC: challenges and opportunities', International Criminal Law Review, 11(4), pp. 775-802.

Munyard, T. (2010) Are these international courts, courts of justice? Presented at the Institute of Social Studies (ISS) Development Research Seminars. The Hague: International Institute of Social Studies. 
Mutua, M. (2000) 'What is TWAIL?', Proceedings of the ASIL Annual Meeting, 94, pp. 3138.

Mutua, M. (2001) 'Savages, victims, and saviors: The metaphor of human rights', Harvard International Law Journal, 42, pp. 201-245.

Mutua, M. (2010) The International Criminal Court in Africa: challenges and opportunities. (NOREF Working Paper No. 3). Oslo: Norwegian Peacebuilding Centre.

Nelken, D. (2004) 'Using the concept of legal culture', Australian Journal of Legal Philosophy, 29, pp. 1-26.

Neumann, R. (2000) 'Donald Schön, The reflective practitioner and the comparative failures of legal education', Clinical Law Review 6(2), pp. 401-426.

Nouwen, S. (2013) Complementarity in the line of fire. Cambridge: Cambridge University Press.

Nouwen, S. \& Werner, W. (2011a) 'Doing justice to the political: the International Criminal Court in Uganda and Sudan', European Journal of International Law, 21(4), pp. 941965.

Nouwen, S. \& Werner, W. (2011b) 'Doing justice to the political: The International Criminal Court in Uganda and Sudan: A rejoinder to Bas Schotel', European Journal of International Law, 22(4), pp. 1161-1164.

Orentlicher, D. (2003) 'Judging global justice: assessing the International Criminal Court', Wisconsin International Law Journal, 21(3), pp. 495-512.

Quigley, F. (1996) 'Seizing the disorienting moment: adult learning theory and the teaching of social justice in Law School Clinics', Clinical Law Review, 2(1), pp. 37-72.

Reynolds, J. (2017) Empire, emergency and international law. Cambridge: Cambridge University Press.

Risse, T., Ropp, S. \& Sikkink, K. (1999) The power of human rights: international norms and domestic change. Cambridge: Cambridge University Press.

Sands, P. (ed.). (2003) From Nuremberg to The Hague: the future of international criminal justice. Cambridge: Cambridge University Press.

Scheppele, K. (2004) A Realpolitik defense of social rights. Texas Law Review, 82(7), pp. 1921-1962.

Schotel, B. (2011) Doing justice to the political: The International Criminal Court in Uganda and Sudan: a reply to Sarah Nouwen and Wouter Werner. European Journal of International Law, 22(4), pp. 1153-1160.

Shalleck, A. (1995) 'Clinical contexts: theory and practice in law and supervision', New York University Review of Law and Social Change 21(1), pp. 109-182.

Special Court of Sierra Leone (2004) 'Prosecution opening statement, trial of the RUF accused', Case No. SCSL-2004-15-PT. Freetown: Sierra Leone.

Sieff, M. \& Vinjamuri, L. (2002) 'Prosecuting war criminals: the case for decentralisation', Conflict, Security and Development 2(2), pp. 103-113.

Teubner, G. (1983) 'Substantive and reflexive elements in modern law', Law and Society Review 17(2), pp. 239-286.

United Nations (1945) Charter of the United Nations. United Nations Treaty Series, v. 1. San Francisco: United Nations.

United Nations (1948) Universal declaration of human rights. United Nations Treaty Series, v. 660. New York: United Nations.

United Nations (1966a) International covenant on civil and political rights. United Nations Treaty Series, v. 999. New York: United Nations. 

Crises: Dynamics, Construals and Lessons (2018, London: Routledge).

United Nations (1966b) International covenant on economic, social and cultural rights. United Nations Treaty Series, v. 993. New York: United Nations.

United Nations (1984) Convention against torture and other cruel, inhuman or degrading treatment or punishment. United Nations Treaty Series, v. 1465. New York: United Nations.

United Nations (1998) Rome statute of the International Criminal Court. United Nations Treaty Series, v. 2187. New York: United Nations.

Voyvodic, R. \& Medcalf, M. (2004) Advancing social justice through an interdisciplinary approach to clinical legal education: the case of legal assistance of Windsor. Journal of Law and Policy, 14, pp. 101-132.

Wessels, M. (2006) Child soldiers: from violence to protection. Cambridge, MA: Harvard University Press.

Wilt, H. van der (2011) 'Universal jurisdiction under attack: an assessment of African misgivings towards International Criminal Justice as administered by Western states', Journal of International Criminal Justice, 9(5), pp. 1043-1066.

Yates, P. (director) (2003) The Reckoning: The Battle for the International Criminal Court (2003) (Documentary film). Available: Skylight Pictures.

Zegveld, L. \& Handmaker, J. (2012) Universal jurisdiction: state of affairs and ways ahead: a policy paper. ISS Working Papers Series, no. 532. The Hague: International Institute of Social Studies. 